Journal of Education and Educational Development

7(2), 351-368, 2020

DOI: http://dx.doi.org/10.22555/joeed.v7i2.26

\title{
Iqbal and Modern Islamic Educationists, Part 1: The Perceived Aims and Objectives of Education - A Comparative Analysis
}

\author{
Muhammad Abid Ali \\ captainmabidali@yahoo.com \\ Bahria University, Pakistan \\ Suhailah Binti Hussien \\ suhailah@iium.edu.my \\ International Islamic University, Malaysia
}

\begin{abstract}
Iqbal views the schooling as well as the Madrassah systems devoid of developing a dynamic Muslim required for the renaissance of Ummah. With this realization, many Islamic educationists in Pakistan have established. Islamic schools in Pakistan. The question is whether their models are dynamic enough to create such Muslims? This research probes into the perceptions and practices of ten Islamic school educationists in Pakistan. It also probes and clearly elaborates Iqbal's educational directives, and finally does a comparative analysis of Iqbal's directives with the Islamic educationists' perceptions and practices. Exploring Iqbal's educational thought includes qualitatively drawing hermeneutical interpretations from Iqbal's two Persian anthologies of Asrar i khudi (Secrets of the Self), and Ramooz i bikhudi (Mysteries of Selflessness). Thematic data analysis was used to draw the aims and objectives for education from Iqbal's said works. It was discovered that though the Islamic educationists carried some visions of education from Islamic perspective, they were largely following contemporary secular frame work of education in attempting to achieve these objectives. The contemporary schooling framework has been severely critiqued by Iqbal and is deplored by many educationists in the west as well for its ineptness to confirm with child's learning psychology. This project was undertaken as my doctoral research and is presented
\end{abstract}


in two parts. The first part elaborates the aims and objectives as conceived by these Islamic educationists, and as derived from Iqbal's educational philosophy. The second part of this paper will elaborate the practices of these educationists with Iqbal's educational directives.

Keywords: aims and objectives of Islamic education, Iqbal's educational philosophy, Islamic education, Islamic schools, Islamic educationists

\section{Introduction}

It is odd to observe that the Islamic countries by large are adhering to an education system which is designed by the west to achieve its own secular objectives (Ali, 2011, 2016; Herrera, 2004). When we adopt an alien education system, it is but natural that our children will experience that alien narrative around which the education system has been developed; Western systems naturally depict western culture (Ali, 2011; Asad, 2005; Maudoodi, 2000; Qutb, 1979). Moreover, the issue is not only that the western education exposes our youth to western ideology and philosophy; the system is not even compatible with a child's learning psychology (Holt, 1995; Gatto 2005, 2009; Robinson, 2009, 2010; Rafiuddin, 1983). We observe Muslim scholars and educationists actively seeking to find a solution to this issue. In his book on Iqbal, Nadvi (1972) has emphasized that individuals should be educated and trained to lead the society towards success and development - the major function of education. Although Iqbal's entire poetical and prose literature is devoted to this cause, his two Persian poetical masterpieces, Asrar-i-khudi (Secrets of self) and Rumuz-i-bikhudi (Mysteries of selflessness) exclusively deal with these aspects. In the words of (Tufail, 1966, p.32): "While Asrar-i-khudi deals with the problem of individual in relation to its internal integration and development, Rumuz-i bikhudi deals with individual in relation to society ... its basis, its aims, ideals, and ways and means of attaining them".

Iqbal was highly critical of both the modern schooling system as well as the madrasahs. He claims that both have failed to produce the necessary level of character, faith, zest and zeal in the youth. The youth has fallen prey to the easy and leisure life, and are not mindful of higher Islamic objectives (Ali 2010; Bilgrami 1966; Hakeem 2005; Iqbal 1964; Nadvi 1969). About the secular educational system prevalent in the east, Iqbal says: 


\section{Alas! The young and hot-blooded schoolboy \\ Is falling a helpless victim to the Western sorcerer. \\ (Iqbal as cited in Rahman, 1984, p.57)}

And for the traditional madrassah education he complains:

I rose downhearted from Madrasa and Khainqa where,

Neither life is promoted nor love nor knowledge nor vision

(as cited in Nadvi, 1979, p.61)

Iqbal (1944) was a strong proponent of intellectual freedom and creativity. He has described the self as an inherently and fully active and creative entity, which has to be provided with freedom for growth. According to Iqbal, this freedom has to be within the limits of the shariah.

For this research, Iqbal's two anthologies Asrar-i-khudi and Rumuz-i-bikhudi were used to extract aims and objectives of education from Islamic objective. It is worthy to note that Iqbal (1953) assertively claims that whatever he has written in these two anthologies conform fully to Qur'anic teachings.

This article mainly makes a comparison of aims and objectives of education as enunciated by one of the greatest Muslim philosopher of the last century Dr. Allama Muhammad Iqbal, which has been compared with the perceived aims and objectives.

\section{Methodology}

This paper is extracted from my $\mathrm{PhD}$ thesis titled: An analysis of conceptions and practices of Pakistani educators in private Islamic schools in light of Iqbal's educational philosophy. Iqbal's two anthologies Asrar-i-khudi (Secrets of the Self), and Ramooz- $i$-bikhudi (Mysteries of Selflessness) were selected for this research. These two collections of philosophical poems were analyzed using hermeneutics approach for exegetical interpretation of his poetical verses. Theoretical qualitative analysis was conducted to investigate Iqbal's philosophy of education and to draw aims of education from Islamic perspective as envisaged by Iqbal. Critical review of the Urdu and English translations of the aforementioned 
anthologies was conducted and key words, main ideas and concepts were identified. The translated verses were at times referred to the original Persian text for understanding the actual spirit behind a verse. Contextually, the meanings were derived and interpreted into themes.

The key ideas and concepts derived were brought down into a written analytical format. From the derived themes, raw aims of education were drawn. For the issue of validity and credibility in research, at each stage the work was reviewed and assessed by an expert on Iqbal who has received recognition and awards for his works on Iqbal. After a number of sessions and deliberations with the expert, the analysis was finalized for refining the educational aims. After refining the aims of education, the exercise of review and deliberations with the expert was repeated.

Data for the modern educationists was collected from ten Islamic schools, which were selected by purposive convenient sampling. The respondents were mainly the visionaries of these schools. These schools were following either Matriculation or Cambridge system of education, and not Dars-e-Nizami. The main method for data collection was interviews of the respondents. Other methods used were field notes, informal interviews with principals, coordinators and department heads, syllabus books review, class observation, and other relevant documents review.

\section{Aims and Objectives of Education - Iqbal}

Iqbal (1944) stresses that each individual has to play his role as a vicegerent of the Creator, and as such has to be developed into a 'self-contained exclusive center' (p. XIX) through education. An individual who is fully prepared to take up the responsibility as Khalifa of the creator and account for his/her actions as such on the last day of judgment (Iqbal, 2003). This role has to be played while being associated with the Ummah or community. In Iqbal's educational thought, the development of self takes precedence over all other aims and activities in education (Mir: 2006; Saiyidain, 1977; Tufail, 1966) as such, his prime focus is on the development of this self. The below aims have been derived from Iqbal's Asrar-i-khudi (1944), and Ramooz-i-bikhudi (1953). 


\section{Realization of the Function of Khudi or Self}

Iqbal's first concern is to elaborate the functions of Khudi or individuality. He explains that the human self or individuality is a highly creative and proactive entity and endeavors for self-growth. Creating challenges and then subduing them makes it stronger. It requires freedom to grow. Iqbal (1944) asserts that human beings are inherently very creative and desirous by nature. The human self will make life purposeful by creating ideals and actively pursuing them.

\section{Realization of Being Creator's Vicegerent}

Another aim is creating the spirit and realization of being the Creator's vicegerent on this earth and the implications this responsible position demands from us. For Iqbal, a very strong selfis an essential prerequisite for a God's vicegerent or khalifa on the earth. This selfcan be strengthened by intense passion and high self-respect, while it can be weakened by an attitude of begging and dependency. For Muslims, Iqbal elaborates, this passion is derived from the love of the Prophet (P.B.U.H.) (and his Sunnah). The Prophet (P.B.U.H.) conducted all his worldly affairs through religion only, which we too should emulate. Iqbal motivates individuals to ask from the Creator alone, as this will develop the strength required of His vicegerent. On the other hand, if a person resorts to begging from the created, his self-respect will be crushed and his strength annihilated. He emphasizes that this dependency on the creation has degraded the contemporary Muslim Ummah, while the latter apologetically term this attitude as sabr or patience.

\section{Practicing as per Belief}

Iqbal wants education to develop the quality of praxis among the Muslims. They should practice what they believe in and harbor a practical attitude towards life, i.e. proactively work for desires. He emphasizes that desire leads man to overpower nature.

Whatsoever is good and fair and beautiful,

Is our guide in the wilderness of seeking (Iqbal, 1944, p.61).

He urges Muslims to develop an attitude of praxis - putting theories into practice. 


\section{Development of Self}

Iqbal elaborates that education for the development of self has three sequential stages: obedience, self-control, and Divine Vicegerence. He asserts that since all things in this world follow Creator's laws, man too can acquire harmony and stability through obedience to God. He says:

Since Law makes everything strong within, Why dost thou neglect this source of strength? (Iqbal, 1944, p.74)

Iqbal considers the five pillars of Islam as institutions for the training of the self. As Shafique (2010) puts it: 'The five pillars of Islam are meant to help you tame the beast in you so that you may have an easy ride'. To be the God's vicegerent, Iqbal presents a long list of tendencies and qualities to be emulated by individuals through education, which include: realization of accountability as a vicegerent and prophetic missionary, creativity, imagination, deep and creative interest in natural and social sciences, and motivation for using these for the benefit of humankind, zest for service to humanity, etc. Here, Iqbal present the role model of the Prophet's (P.B.U.H.) companion Ali (R.A.). This is a very effective technique in education, where behavior modification is encouraged through popular human role models.

\section{Establishing Allah's World Order}

Another important aim that Iqbalpresents is the realization that effort to establish Allah's (S.W.T.) order in this world as the main objective of life, and explication of the correct concept of jihad. 'Color oneself in the color of God', is Iqbal's advice to us. He exclaims that every act of a Muslim is for his God alone and a Muslim is fully absorbed in His love and obedience. He explains that when a Muslim pitches his tent in the field of tawhid, he becomes a role model for humanity — a witness to humankind as prescribed by the Qur'an. Iqbal explains the concept of jihad as a sincere effort to establish God's world order in this world; it is not merely a lust for more land. If it is not for God's sake, then the pursuit of even peace is transgression against Him. Education should effectively pursue this aim, firstly, to prepare human resource for the establishment of the Creator's world order, and secondly, it is in these efforts of establishing God's order that an individual's success or failure in the next eternal life depends. 


\section{Self-Development and Self-Reliance}

Another important educational aim for Iqbal is motivation for conscious self-development and achieving self-reliance. Iqbal claims that every person is strictly unique in his disposition, as he alone will face the accounting before his Creator with no intercession. As such, Iqbal's target is the development of the individual self. Each person has to acquire knowledge for his self-development and for understanding the truth. He warns that the contemporary trend in knowledge is destructive for this self. It is totally devoid of any spiritual fervor. Here, Iqbal motivates the Ummah to realize its worth and not to be overawed by western knowledge. He urges the Ummah to develop its own identity and individuality, and have confidence in the Creator's guidance and in the role model of the Prophet (P.B.U.H.). Iqbal advises Muslims to refrain from cursing destiny; rather, they should create their own destiny. He emphasizes that the progress the West so prizes today is our(historical) left-over only. He reminds us that we have been made the custodians of the two worlds and have the best leader in our Prophet (P.B.U.H.). This powerful message communicated to the Ummah calls for a lot of reflection on our part from the educational perspective. We should ponder over whether or not we are approaching the education of our young from these perspectives.

\section{Muslim's Connection with Millah}

After focusing on the development of the self, Iqbal comes to the task of defining the relation and functioning of this developed unique individual within the community - the millah. In this perspective, the first aim he presents is the realization and preparation for an individual's role in the development of society. Without realization, no motivation can be created and no praxis can be achieved. Iqbal explicates that since Muslims are the last Ummah and no other prophet is expected, the establishment of God's order has been delegated to this last Ummah. Muslims are expected to be the Creator's vicegerent, his representatives on earth. This implicates that each individual of this Ummah has to realize his/her delicate situation and colossal responsibility, and develop his/her self for this task of collective vicegerency. Iqbal rationalizes that this task can only be achieved collectively. The achievement of this task should become the desire and obsession of each Muslim. Iqbal complains that Ummah has made the west their yardstick and have alienated from the spirit of Islam. The Ummah has to revert to the code of life brought by the Prophet (P.B.U.H.), which is his only guarantee to success in 
both the worlds. The realization of this precept has a serious educational implication, which should be inculcated in the Muslim youth.

\section{Foundations of Muslim Nationhood}

Next, Iqbal defines the constituents of the concept of Ummah which he asserts should be communicated to Muslim individuals. The foundation and structure of every system is developed on some philosophy. For a Muslim nation, it should be Islamic philosophy. For a long time now, Islamic countries are firmly rooted in an educational system developed on the foundation of western philosophy. Iqbal feels the importanceofdefiningthe foundational concepts of Muslim nationhood, which needs to be well integrated into our educational philosophy.

\section{Tawhid (Belief in One God) as National Binder}

Iqbal explains that this concept generates self-efficacy and self-sufficiency. Tawhid can bring diverse nations together and instill the best vigor for thought and action collectively; it is the gravity which keeps us all together. Then, he explicates that we are united under the banner of the last Prophet (P.B.U.H.), and, being the last Ummah, are responsible for the propagation of his (P.B.U.H.) message of mercy for the whole world. Brotherhood is one of the most prominent features in the Muslim Ummah, which transcends all ranks, races, colors, and creed. Two other foundational features of this brotherhood are justice and equality.

\section{Islamic Justice and Equality}

Iqbal narrates a scene of a court, where a Muslim king is summoned by the judge for a criminal offence against his common subject:

And summoned to his court the unjust king

Who, hearing the Koran invoked, turned pale

With awe, and came like any criminal

Before the judge, his eyes cast down in shame (Iqbal, 1944, p.40).

Islamic justice and equality is unparalleled in the history of any other nation. The kingdom is of God alone. Bowing to the commands of one God removes all other bondagesand Iqbal projects this as the foundation of Muslim 
nationhood, where the purpose of a Muslim's life is to liberate the world from the tyranny of other demigods. Since the Ummahis united on the universal truth of tawhid, it cannot be restricted to a geographical boundary and as such is trans-national and universal. Iqbal reminds that the Prophet (P.B.U.H.) never associated himself with any land and his (P.B.U.H.) hijrah gives us the same lesson. Iqbal grieves that the Muslims are spiritless, as they are associating themselves with land instead, which is an alien concept and against the spirit of Islam. Iqbal teaches that making land as a basis of nationhood has destroyed the brotherhood of human beings.

\section{Muslim Nationhood}

The essence of this Muslim nationhood has to be inculcated as an aim of education. Iqbal reminds of the fact that when a man dies, his soul leaves the body; however, a nation dies only when it forsakes the purpose of its existence and forgets its traditions. The message of the Prophet (P.B.U.H.) will remain until the end of time and as such, this Ummahis not bound by time either. Explaining the significance of obedience to the edicts of the Qur'an,Iqbal says:

When a Community forsakes its Law,

Its parts are severed, like the scattered dust (Iqbal, 1953, p.51).

\section{Quran as Guide}

When millah moves away from its law, it loses identity and unity. Everything in this universe survives by following some law, and the law for this Ummah is the Qur'an. Iqbal lays extensive stress on the understanding of the Qur'an, as it is thislaw which has to be followed by each individual of the Ummah. He reminds that the Qur'an transformed slaves into masters and the loftiest of thrones went under their feet. These Muslims established great traditions wherever they went. Iqbal laments that now the Ummah's hearts are trapped and awed by the unbelievers' ways. Muslims have drifted away from the Qur'an in the last few centuries, and are generally ignorant of Qur'anic precepts in these times. Iqbal recommends that we hold fast to the traditions of our great predecessors. Iqbal motivates Muslims to seek guidance from Qur'an:

Seek thou no other meaning in the Law,

Nor look save light to find within the gem (Iqbal, 1944, p.56). 


\section{Shariah as law}

Iqbal explicates that the Shariah is the only law and is eternal, the only criterion to judge one's loyalty to Creator. It is the tool for internal and external purity; in losing the teachings of Qur'an, the Ummah has lost the secret recipe. He further asserts that following the Prophet's (P.B.U.H.) way is the only best course for Ummah to follow. The Ummah should feel the responsibility for preparing their young for the day of accountability and judgment.

\section{Unity of Center}

Iqbal sees the secret of Ummah's unity in rallying around one centre, which is the Kabah. He narrates that when the Jews lost their centre, they were dispersed in different places. Iqbal also reminds the Muslims about their lofty ideal of the propagation of tawhid, for which this Ummahhas been selected, and will be accounted for, and this is what binds them together. He exhorts Muslims to proactively seek knowledge and harness nature. He claims that knowledge and technology bring confidence to a nation; this is what is required of world leaders.

Speaking further on the foundations of a nation, Iqbal explicates that knowledge of nation's great history brings identity and strength to a nation's collective individuality, or self, by which a nation develops a collective ego, a strong identity. If the history is lost, the community loses its identity and self. As such, we, as a Muslim nation, should hold fast to our traditions and national history.

\section{The Role of Motherhood}

After reminding the Ummah of its foundational precepts, Iqbal acknowledges that thecontinuance of the species derives from motherhood, and that the preservation and honoring of motherhood is the foundation of Islam. Iqbal says, like Prophets, women are the architects of a nation's character and destiny:

And her compassion is the Prophet's own.

For mothers shape the way that men shall go (Iqbal, 1944, p.77).

In contrast, Iqbal defines westernized women in the following words:

Her learning is inadequate to bear

The charge of motherhood, and on the dusk 


\section{And evening of her days not one star shines (Iqbal, 1944, p.78).}

Iqbal reminds Muslim women of their great task and puts forward the role model of Fatima, the Prophet's (P.B.U.H.) daughter, to emulate. The comprehensiveness of Iqbal's message for education can be observed from the exhaustive variety of subjects that he has covered in Asrar $i$ khudi and Ramooz $i$ bikhudi. These can provide an appropriate and effective model for an educational system from the Islamic perspective.

\section{Aims and Objectives of Education - Conceptions of Islamic Educationists}

For this qualitative research, ten Islamic Educationists were selected as sample. These educationists carry various visions behind their educational projects in terms of providing education from the Islamic perspective. These include: removing educational dichotomy of Madrassah and normal schools and developing unity of education under an Islamic educational system, understanding and implementing the concepts of the Qur'an as a vision, creating God-fearing leaders, checking the decline of the Ummah, bettering the society through tarbiah, and developing a healthy society through an improved literacy rate, and inculcation of Islamic values. Under these visions, the educators elaborated various educational aims for different aspects. From the aspect of personality, they include: developing God-consciousness, creating feelings of awe and omnipresence of Allah (S.W.T.), developing love and fear of Allah (S.W.T.), inculcating different traits of an Islamic personality, developing human character on the foundation of Islamic values and culture, teaching how to emulate the Prophet (P.B.U.H.) and his companions as role models, imbibing the personality of God's khalifa as mentioned in the Qur'an, teaching appropriate conduct in daily life, developing good and decent people, developing professionals and intellectuals with an Islamic world view, developing the intellect to a level where one's worldview is based on logical arguments and the attitude of accepting such arguments, clarifying the status and position of all creations in children's minds (adab as per al-Attas, 1979). Thus developing perspicacity in individuals, and developing a 'wholesome broad-minded human'. From the Qur'anic perspective, three approaches observed were: hifz for future understanding of the Qur'an at specialization stage, understanding the Qur'an right from school-going age, and exploring the Qur'an for profiling God's desired personality. It is worth noting that only two educators explicitly mentioned the conformity of actions with the Qur'anic teachings. Whereas, implicitly, it can be 
assumed that all the sampled educators have a natural understanding of this facet. However, explicit mentioning does demonstrate the priority of an intention.

From the social aspect, the following were specified: development of social responsibility as an aim of education, teaching supremacy of adl or justice, best service to the community, developing responsible citizens, establishing one's correct relation to society, developing into good Muslims who are 'beneficial to all and to society', and 'invite people towards what is right and forbid (discourage) what is wrong'. This, along with developing a connection with Allah (S.W.T.), will help children become productive and a very important member of their society,

From the perspective of inculcating confidence in one's culture and traditions, only two out of ten educators perspicuously talked about the development of confidence and pride in one's Islamic value system, culture, and traditions, rather than having any inferiority complex in this respect. One asserts that developing pride in Islamic culture and values is high on the education agenda. Only these two mention the western culture as harmful.

On the matterof dichotomy in contemporary education, four mentioned educational dichotomy as an issue of concern. Two explicitly express that in Islamic education, this dichotomy does not exist. One was of the view that religious and worldly educations have to be 'blended'. One blames this dichotomy as the cause of the present chaos in Pakistan.

To achieve their conceived aims for education from the Islamic perspective, it was observed that the respondents have different approaches and various objectives, which include: introducing hafiz individuals to all professions and equipping them with basic Arabic grammar to facilitate the understanding of the Qur'an when they grow up and acquire further Islamic specialization. Other approaches are: to equip the students with love and fear of the Creator to motivate them to follow Allah's (S.W.T.) commands, develop Islamic personality traits in children through school education, amalgamate religious and worldly education to develop Islamic professionals, integrate Islamic knowledge into secular knowledge, make Islam the core concept in full syllabus and refrain from doing just the 'patch work' of Islamic integration in education, develop the personality of the Prophet (P.B.U.H.), learn simple values and Islamic culture at the basic level, and 
provide broad Islamic studies in the light of modern sciences and social disciplines. From the academic perspective, quality education of an international standard should be provided in an environment conducive to achieving Islamic values; implement a strong academic program to meet the admission requirement of prestigious schools and universities at home and abroad; etc.

These educators are serious and generally seen working for the perceived Islamic objectives. However, the issue of effectiveness from the pedagogical perspective is debatable.

On the issue of syllabus, schools ranged from more than 50 percent customization to nearly nil customization of text-books from the Islamic perspective as per the researcher's inspection of the syllabus books. Many books, especially the English language and science books, reflected western culture and secular approach. However, it was observed that at different levels the school was endeavoring to train their teachers to integrate Islamic concepts in different subjects while teaching. It was also observed, however, that a substantial number of Urdu language text books project the Islamic dress code only while presenting Islamic concepts or portraying elderly and theunderprivileged people;whereas, educated and professional individuals significantly digress from the Islamic dress code. The principal of one of the sample schools, using British-published English language books, informs that students of pre-nursery, age group of 3 to 5 years, were informed by the teachers about all the non-Islamic contents in their textbooks,in their lessons. .

With the exception of two schools, none of the other sampled schools was observed integrating the concept of the Creator in their science text-books, to depict scientific facts as signs of the Creator. It is noteworthy that six of the ten schools were following the British GCE syllabus; three were offering only Matriculation, and one school was offering both the streams at their different campuses. It is significant to note that one of the respondents is arranging a Qur'an class with no assessment procedures to make the study of the Qur'an interesting for the students. This implicitly depicts the fact that other subjects, which are assessed routinely, are not considered as interesting by the students.

From the perspective of inculcating an Islamic personality and qualities of 
leadership, all ten sample schools are basically focusing on developing an Islamic identity for their children. However, they differ in their approaches and methodologies. Three schools concentrate on the Islamic studies subject as the main tool for creating Islamic personalities. Other approaches include: hifz as a tool to guide a person through his/her life; focus on the inculcation of Islamic manners or adab; development of love and fear of God for effective obedience of His commands; consciousness of an individual's mission in life; a deep sense of belonging to Islam;development of a balanced personality; and, inspiration for following Prophet Muhammad's (P.B.U.H.) role model. A respondent cautions about the effects of hidden curriculum and another respondent about a special objective for a special project to liberate the oppressed, illiterate masses from the yoke of feudalism through self-realization and Islamic awareness.

Islamic roots play an important part, especially when we look at personality from an Islamic perspective; this as a big issue in the present Islamic world. This was pointed out by some respondents, where they see the prevalent trend harmful, and endeavor to ground children in the Islamic value system and culture. A respondent reminds: 'You know your role model'— the Prophet (P.B.U.H.). The educators emphasized the importance of school and external environments; they assert that without the required environment "all becomes just theory". The need for teachers' orientation towards an Islamic perspective was also felt by some.

Six out of ten respondents associate learning of the Arabic language for a good understanding of the Qur'an. Although six schools were also facilitating hifz or memorization of the Qur'an, two did not feel the importance of directly understanding the Qur'an at the school-going age.

\section{Discussion and Conclusion}

Iqbal (1944) complains that Ummah has made the west their yardstick and has alienated from the spirit of Islam. He warns the Muslims not to copy west and to develop confidence to establish their own systems based on Qur'an and Sunnah. Iqbal (2011, p. 366) points out that we as Muslims have an entirely different makeup of life:

Judge not your nation on the criteria of Western nations

Special in composition is the Hashimi Prophet's nation (Bang e Dara). 
The systems developed by west are based on their outlook of life and their assumptions about human being and its function in this life. Their schooling system is based on their worldview and developstheir minds and not Muslims' minds and thus Iqbal (2011, p.795) says:

The pupil in schools looks alive; nay, he is dead;

He had borrowed his breath from the Franks (Zarb e Kaleem).

The issue is that the contemporary school system is developed by the west and very delicately structured educational programs have been designed around their understanding of human being and their objectives of life which totally contradicts the Islamic worldview. It is observed that this fact is largely ignored by the Islamic educationists and they have implemented the western system of education with some syllabus changes by adding a subject or two. By large, the educational approach and interventions are secular and as such develop secular perceptual framework in the students. This was observed in all the ten sample Islamic schools. Although their presumed aims and objectives do sound Islamic, their educational procedures and material are heavily adopted from the western secular education with very little consideration ofhuman psyche which Iqbal thoroughly delves in. Iqbal, (1944) points out that ummah's hearts are trapped and awed by the unbelievers' ways which is totally devoid of any spiritual fervor. Iqbal warns that Ummah should not be overawed by the western knowledge, and should endeavor to develop its own identity and individuality.

It was observed that the focus of these educators was more onthe results, rather than the appropriateness of the processes to achieve the desired results. They lacked the in-depth understanding of the natural procedures of human learning, which Iqbal has focused upon. Although the educators were wishful to develop Islamic traits among their students, however their procedures ranged from Hifz e Qur'an or teaching of other Islamic literature to adopting superficial Islamic mannerism. Iqbal is more focused on the spirit behind an action rather than just action; whereas, the respondents largely failed to realize the negative effects of western schooling.

Iqbal's main focus is on the ego or Khudi. He relates individuality and self-realization as the basis of human development. A strong ego is a pre requisite 
foran effective representative of God on earth. Education should focus on developing strong individuality and high self-esteem. This Iqbal considers as the most important aspect of education which gives an individual a strong self-identity. It is significant to observe that although the respondents were vocal about Islamic personality and values, they failed to mention from the perspective of individuality or self-identity. It is also worthnoting that all the respondent were following factory model of schooling where the individuality is compromised in favor of the process of mass education system called schooling.

Iqbal points out that the understanding of the function of Khudi or individuality and self-realization is a valueaddition for an educator as it is a prerequisite for educating. None of the ten educationists dealt with this aspect of human growth in their educational aim and objective.

For Iqbal, the process of 'learning' or 'education' is an internal function of each human being, as it is self-motivated and self-generated. None of the respondents mentioned this aspect of education to the children. All the schools followed external interventional procedure of education, in which a prescribed curriculum is imposed on the children.

For Iqbal, self-realization of each individual is the most essential featurefor performing as God's representative, or Khalifa. This self-realization is from two perspectives: i) knowing one's own self and one's own God gifted capabilities; ii) operationally utilizing these capabilities for self and community development. This self-realization is possible under non-repressive environment where each individual is given due recognition, respect and freedom to develop independently. Iqbal considers learning as natural and self-directed whereby each individual is programmed to take up challenges. This depth of understanding about the educational procedures was not observed amongthe respondents exceptfor one.

Iqbal describes education or learning as an individual's activity, becauseeach individual is equipped with the natural desire to create and accept challenges which isan activity of their ego (khudi). Thus learning is regarded asthe process of surmounting a challenge, climbing up the ladder of ego consolidation. Each individual is born with intense inherent ego (khudi), which yearns to grow by taking up formidable challenges and in the process learns actively.. This can very 
well be observed in young children who are continuously engrossed in taking all tasks as a challenge and rarely approve external intervention or help. Whereas western secular approach to education is mostly based on external interventional learning and attempts to educate groups of children in a collective manner. The Islamic educationists limited their notion to the western popular approach to education. It is worth noting that contemporarily many western educationists like Robinson (2010), Holt (1995), Gatto(2009)have severely criticized this western approach to education and bent heavily on learning as a function of self-realization enunciated of Iqbal. Iqbal considers the five pillars of Islam as important tools for human development from the perspective of preparation for the role of Creator's vicegerent. This was not covered or demonstrated by any of the ten Islamic educationists. In all the sample schools it was observed that the five pillars of Islam were taken as passive activity and least connected to human education and development.

\section{References}

Al-Attas, S. M. N. (1979). Introduction. In (eds). Aims and objectives of Islamic education.(pp. 1 -15). Hodder \& Stoughton.

Ali, M. A. (2011). An analysis of conceptions and practices of Pakistani educators in private Islamic schools in light of Iqbal's educational philosophy (Doctoral dissertation, Institute of Education, International Islamic University Malaysia).

Ali, M. A. (2016). Islamic and Western education systems- perceptions of selected educationists in Malaysia. Journal of Education and Educational Development, 3(2), 250-276.

Asad, M. (2005). Islam at the crossroads. The Other Press.

Bilgrami, H. H. (1966). Glimpses of Iqbal's mind and thought: Brief lectures on iqbal delivered at London, Cambrigde and Oxford. Sheikh Mohammad Ashraf.

Gatto, J. T. (2005). Dumbing us down: The hidden curriculum of compulsory schooling. New Society Publishers.

Gatto, J. T. (2009). Weapons of mass instructions: A school teacher's journey through the dark world of compulsary schooling. New Societ Publishers.

Hakeem, K. A. (2005). Fikr e Iqbal (7th ed.). Bazm e Iqbal.

Herrera L. (2004). Education, Islam, and modernity: Beyond westernization and centralization. Comparative Education Review, 48(3), 318. 
Holt, J. C. (1995). How children fail. Addison-Wesley Pub. Co Iqbal, M. (2011). Kulliyat-e-Iqbal. Fazlee Sons.

Iqbal, M. (1944). The secrets of the self: (Asrar-i-Khudi) Aphilosophical poem (Revised ed.).Sh. M. Ashraf.

Iqbal, M. (1953). The mysteries of selflessness: A philosophical poem. J. Murray. Iqbal, M. (2003). The reconstruction of religious thought in Islam (4th ed.). Ilm-o-Irfan Publishers.

Iqbal, S. M. (1964). Thoughts and reflections of Iqbal. (S. A. Vahid, Ed.) Sh. Muhammad Ashraf.

Kazmi, Y. (1999). The notion of Murabbi in Islam: An Islamic critique of trends in contemporary education. Islamic Studies, 38(2), 209-233.

Maudoodi, S. A. (2000). The education. Markazi Maktaba Islami.

Mir, M. (2006). Iqbal. I.B.Tauris \& Co. Ltd.

Nadvi, S. A. (1969). Glory of Iqbal (1st ed.). Academy of Islamic Research and Publication.

Nadvi, S. A. (1979). Glory of Iqbal (Vol. Revised). Publishing House.

Nadvi, S. A. (1972). Naqoosh e Iqbal (4th ed.). Majlis Nashriat e Islam.

Qutb, M. (1979). The role of religion in education. In K. A. University, \& S. M. $-N$. al-Attas (Ed.), Aims and Objectives of Islamic Education (pp. 48-62). King Abdulaziz University.

Rafiuddin, M. (1983). First principles of education (2nd ed.). Iqbal Academy. Rahman, F. (1984). Islam and modernity: Transformation of an intellectual tradition. University of Chicago Press.

Robinson, K. (2010, February).TED: Ideas worth spreading.

$\mathrm{http}: / /$ www.ted.com/talks/sir_ken_robinson_bring_on_the_revolution.html Robinson, K. (2009). The element: How finding a passion changes everything. Penguin Group.

Saiyidain, K. G. (1977). Iqbal's educational philosophy (8th ed.). Sh. Muhammad Ashraf.

Shafique, K. A. (2010, March 9). The divine vicegerency.

http://republicofrumi.blogspot.com/2010/03/12-divine-vicegerency.html

Tufail, M. M. (1966). Iqbal's philosophy and education. The Bazm-i-Iqbal.

\section{Citation of this Article:}

Ali, M. A., \& Hussien, S. B. (2020). Iqbal and modern Islamic educationists, part 1: The perceived aims and objectives of education - A comparative analysis. Journal of Education and Educational Development. 7(2), 351-368. 